Voices of Fire

Art, Rage, Power, and the State

On 7 March 1990 the National Gallery of Canada issued a press release announcing its purchase of a large abstract painting by the American artist Barnett Newman for $\$ 1.8$ million. Within 72 hours the gallery was under attack both for its selection of Voice of Fire and for the price tag attached to it. Objections came from across Canada and from all quarters.

The Voice of Fire controversy was the most extensive and heated debate over visual art ever to have taken place in Canada. This anthology can be seen as a case-study, providing both a historical account of the outcome of the National Gallery's purchase of the painting and an understanding of why the gallery's actions provoked such strong opinions and feelings. In this volume the editors also address the peculiar and paradoxical character of abstract art in general, and the problems it consistently poses for viewers. Newman's work is presented as the focus of these concerns.

The attack on the gallery by the press, the general public, Canadian artists, and politicians is documented in the first section by a broad selection of cartoons satirizing the painting, press photographs, news releases, editorials, letters to the editor, and public exchanges. In the second section three essays offer contrasting accounts of the controversy and its significance. The first considers the social processes by which art becomes art; the second focuses on the role of the media in shaping public opinion about art; and the third compares the reception of Voice of Fire in two distinctive frameworks, first at Expo 67 in Montreal, and then in Ottawa in 1990. In the final section, four papers given at a symposium of Voice of Fire organized by the gallery in October 1990 (a combined effort at damage control and art criticism) are presented, as well as a transcription of the public dialogue between speakers and audience that followed.

BRUCE BARBER is an associate professor at the Nova Scotia College of Art and Design. He is an artist and cultural historian, and author of Reading Rooms and Modern Art, Cartoons, Comics and Class Conflict: Cultural Hegemony and the Contest of Power (forthcoming).

JOHN O'BRIAN teaches art history at the University of British Columbia. He is author of David Milne: The Flat Side of the Landscape and Degas to Matisse: The Maurice Wertheim Collection, and editor of Clement Greenberg: The Collected Essays and Criticism.

SERGE GUILBAUT is a professor in the Department of Fine Arts at the University of British Columbia. He is editor of Modernism and Modernity and Reconstructing Modernism, and author of How New York Stole the Idea of Modern Art and Voir, Ne Pas Voir, Faut Voir. 
This page intentionally left blank 


$$
\|
$$


This page intentionally left blank 


\section{Voices \\ of Fire}

ART, RAGE, POWER,

AND THE STATE

Edited by BRUCE BARBER,

SERGE GUILBAUT, and

JOHN O'BRIAN

Introduction by John O'Brian

UNIVERSITY OF TORONTO PRESS

Toronto Buffalo London 
www.utppublishing.com

(c) University of Toronto Press Incorporated 1996

Toronto Buffalo London

Printed in Canada

ISBN 0-8020-0754-6 (cloth)

ISBN 0-8020-7803-6 (paper)

(6)

Printed on acid-free paper

THEORY/CULTURE

Editors:

Linda Hutcheon, Gary Leonard

Janet Paterson, and Paul Perron

\section{Canadian Cataloguing in Publication Data}

Main entry under title:

Voices of fire : art, rage, power, and the state

(Theory/culture)

Includes index.

ISBN 0-8020-0754-6 (bound) ISBN 0-8020-7803-6 (pbk.)

1. Newman, Barnett, 1905-1970. Voice of Fire.

2. National Gallery of Canada - Appropriations and expenditures. 3. Painting, American - Political aspects Canada. 4. Painting, Abstract - Political aspects -

Canada. 5. Art and state - Canada - Case studies.

6. Painting, Abstract - Public opinion. 7. Public opinion-Canada. I. Barber, Bruce. II. Guilbaut, Serge.

III. O'Brian, John, 1944 - IV. Series

ND237.N49A78 $1996 \quad 759.13 \quad$ C96-930573-3

FRONTISPIECE: Barnett Newman, Voice of Fire, 1967. Acrylic on canvas, $543.6 \times 243.8 \mathrm{~cm}$. National Gallery of Canada, Ottawa

Design: William Rueter

University of Toronto Press acknowledges the financial assistance to its publishing program of the Canada Council and the Ontario Arts Council. 